\title{
Perancangan Business Process dan Standard Operating Procedure (SOP) dengan Metode Business Process Improvement (BPI) di Proners Home Care and Nursing Solution Surakarta
}

\author{
Barasena Sayendra Dibsi $^{* 1)}$, Yusuf Priyandari ${ }^{2)}$, dan Roni Zakaria ${ }^{2)}$ \\ ${ }^{1)}$ Mahasiswa Jurusan Teknik Industri Fakultas Teknik Universitas Negeri Sebelas Maret Surakarta \\ ${ }^{2)}$ Dosen Jurusan Teknik Industri, Universitas Negeri Sebelas Maret Surakarta
}

\begin{abstract}
ProNers Home Care and Nursing Solution is a Home Care company established in 2007 in Surakarta Central Java. According the fact that ProNers is a service company that make priority to public service, and also the excalation of ProNers's status to a legal company since July 2012, ProNers needs to redesign the business process and the organizational structure, and to design standard operating procedure (SOP) to carry out their activity. The research uses Business Process Improvement (BPI) method with process reengineering approach which is steps to improve business processes or provide a new processes. First step is to studied the actual business process so we can determine the needs of human resource. Then it will be described in detail in the SOP. The research proposes a more appropriate business process design so the objectives of the company can be achieved. Matrix organizational structure with more focus on job specialization by adding two employees, each of them handle administration and finance division and marketing division. The final design of the SOP consists of nineteen SOPs.
\end{abstract}

Keywords : home care, business process improvement, process reengineering, standard operating procedure.

\section{Pendahuluan}

ProNers Home Care and Nursing Solution merupakan usaha layanan perawatan di rumah (Home Care) yang berdiri tahun 2007 di Surakarta - Jawa Tengah. Didirikan oleh para profesional kesehatan yang berkolaborasi dengan manajemen profesional untuk menciptakan sebuah layanan kesehatan di rumah yang berkualitas tinggi tanpa membedakan status ekonomi dan kepercayaan di setiap wilayah yang dilayani. Sejak didirikan hingga tahun 2012, proses bisnis Home Care di ProNers sudah berjalan meliputi proses registrasi, perawatan, dan pembayaran, namun belum terdapat suatu bentuk standar proses bisnis yang mengatur proses tersebut. ProNers juga belum memiliki susunan struktur organisasi untuk mengatur kewenangan dan tanggung jawab para pelaku proses bisnis di dalamnya. Dalam melakukan perawatan kepada pasien (klien), para perawat ProNers sudah menerapkan Standard Operating Procedure (SOP) perawatan. Selain SOP perawatan, belum terdapat SOP yang mengatur lingkup proses bisnis seperti registrasi, pembayaran, dan proses bisnis lain dalam kegiatan perusahaan Home Care. Secara garis besar, proses bisnis yang berjalan di ProNers dimulai dengan adanya permintaan (demand) dari calon klien, kemudian perawat melayani klien sesuai permintaan klien, dan setelah pelayanan selesai klien membayar perawat, belum terdapat ketentuan khusus yang mengatur perjanjian kerjasama perawatan antara perawat dan klien. Berdasarkan pertimbangan bahwa ProNers merupakan perusahaan jasa yang mengedepankan pelayanan kepada masyarakat, dan peningkatan status ProNers menjadi perusahaan berbadan hukum sejak Juli 2012, ProNers membutuhkan perbaikan berkaitan dengan kondisi proses bisnis, struktur organisasi dan SOP perusahaan.

\footnotetext{
*Correspondance : dibzsai@gmail.com
} 
Menurut Zaheer dkk, (2010), diperlukan suatu skema proses bisnis yang baik karena proses bisnis memiliki pengaruh yang signifikan terhadap karyawan dan performansi organisasi. Dalam pengimplementasiannya diperlukan pengetahuan dari karyawan karena kekurangan pengetahuan akan proses bisnis akan menghambat implementasi proses bisnis (Chong, 2007). Faktor-faktor yang berpengaruh terhadap implementasi perombakan terhadap proses bisnis antara lain dukungan terhadap manajemen, perubahan manajemen, sentralisasi dalam pembuatan keputusan, formalisasi prosedur, budaya organisasi, dan keterlibatan sumber daya manusia yang ada (Ahadi, 2004).

Perbaikan dilakukan dengan melakukan perancangan proses bisnis usulan, hasil perancangan proses bisnis usulan digunakan untuk merancang struktur organisasi dan SOP usulan. Metode perancangan proses bisnis yang digunakan adalah Business Process improvement (BPI). Menurut Harrington (1991), BPI merupakan kerangka sistematis yang dibangun untuk membantu organisasi dalam membuat kemajuan yang signifikan dalam pelaksanaan proses bisnisnya. BPI dapat dilakukan dengan beberapa macam pendekatan, yang meliputi FAST (Fast Analysis Solution Technique) yang merupakan metode dengan cara memfokuskan perhatian grup pada satu proses selama satu atau dua hari, supaya grup dapat memperbaiki proses tersebut untuk 90 hari ke depan. Process Benchmarking yang merupakan metode untuk mengidentifikasi, memahami, bagaimana menghasilkan produk, jasa, desain dan proses yang superior dengan mempelajari organisasi atau perusahaan lain yang bergerak di bidang yang sama. Process Redesign yang merupakan metode yang fokus pada usaha Process Improvement Team (PIT) dalam memperbaiki proses yang ada saat ini. Terakhir Process Reenginering yaitu metode perbaikan proses bisnis yang dilakukan dengan menghilangkan, menyederhanakan, menyatukan atau melakukan otomatisasi pada proses (Indrajit dan Djokopranoto, 2001).

Perbaikan dilakukan berdasarkan keinginan perusahaan untuk mengembangkan kegiatan usaha dan mengantisipasi adanya potensi masalah yang berkaitan dengan standar pelayanan perusahaan hubungannya dengan klien. Metode Process Reengineering memungkinkan perusahaan melakukan perbaikan pada proses bisnisnya sehingga lebih efektif dan efisien dalam pelaksanaannya.

\section{Metode Penelitian}

Metode penelitian pada penelitian ini dilakukan dengan memetakan proses bisnis dan struktur organisasi perusahaan saat ini. Kemudian dilakukan analisis dan perancangan proses bisnis usulan menggunakan metode BPI dengan pendekatan Process Reengineering. Hasil perancangan proses bisnis usulan digunakan untuk merancang struktur organisasi usulan dan SOP usulan. Perancangan struktur organisasi menggunakan pendekatan enam elemen penting struktur organisasi (Robbins, 2002). Untuk menjabarkan lebih detail setiap proses dalam proses bisnis usulan yang telah dirancang sebelumnya, dilakukan perancangan prosedur yang disebut SOP. Metode penelitian pada penelitian ini dapat dilihat pada Gambar 1.

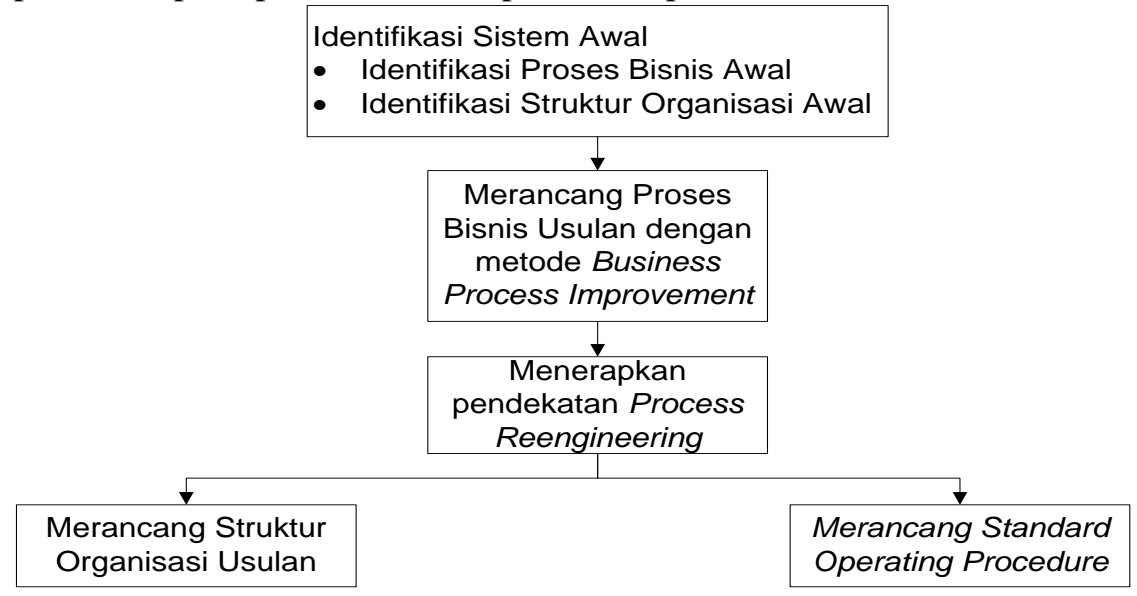

Gambar 1. Metode Penelitian 


\section{Pembahasan}

Dalam perancangan proses bisnis, dibutuhkan data awal yaitu proses bisnis dan struktur organisasi awal perusahaan untuk dapat dianalisis, kemudian hasil analisis digunakan untuk melakukan perancangan proses bisnis. Langkah pertama yang dilakukan adalah memetakan proses bisnis dan struktur organisasi awal perusahaan. Pemetaan ini dilakukan dengan cara observasi langsung pada kegiatan yang dilakukan perusahaan dan wawancara dengan karyawan perusahaan, baik direktur maupun jajaran perawat.

Setelah proses bisnis dan struktur organisasi awal diketahui, maka dilakukan penentuan proses value-added dan non value-added. Penentuan ini penting untuk mengetahui apakah terdapat proses yang tidak efektif sehingga dapat dieliminasi dan apakah terdapat kekurangan pada proses bisnis sehingga perlu ditambahkan proses baru atau bahkan merancang proses bisnis baru untuk memperbaiki proses bisnis yang sudah ada.

Langkah berikutnya adalah melakukan perancangan proses bisnis usulan berdasarkan data dan analisis awal yang telah dilakukan. Hasil perancangan proses bisnis usulan kemudian digunakan untuk merancang struktur organisasi usulan dengan struktur organisasi awal sebagai acuannya. Langkah terakhir yang dilakukan adalah melakukan perancangan SOP berdasarkan proses bisnis dan struktur organisasi usulan yang telah dihasilkan sebelumnya.

\subsection{Perancangan Proses Bisnis Usulan}

Perancangan proses bisnis usulan pada ProNers Home Care and Nursing Solution dilakukan berdasarkan analisis proses bisnis awal dan tetap dijabarkan ke dalam beberapa proses bisnis utama sesuai dengan hasil observasi dan wawancara yang telah dilakukan pada awal penelitian . Proses bisnis utama perusahaan meliputi proses registrasi, proses perawatan, proses pembayaran dan proses komplain. Salah satu contoh hasil rancangan proses bisnis usulan dapat dilihat pada Gambar 2 dan Gambar 3 untuk proses perawatan.

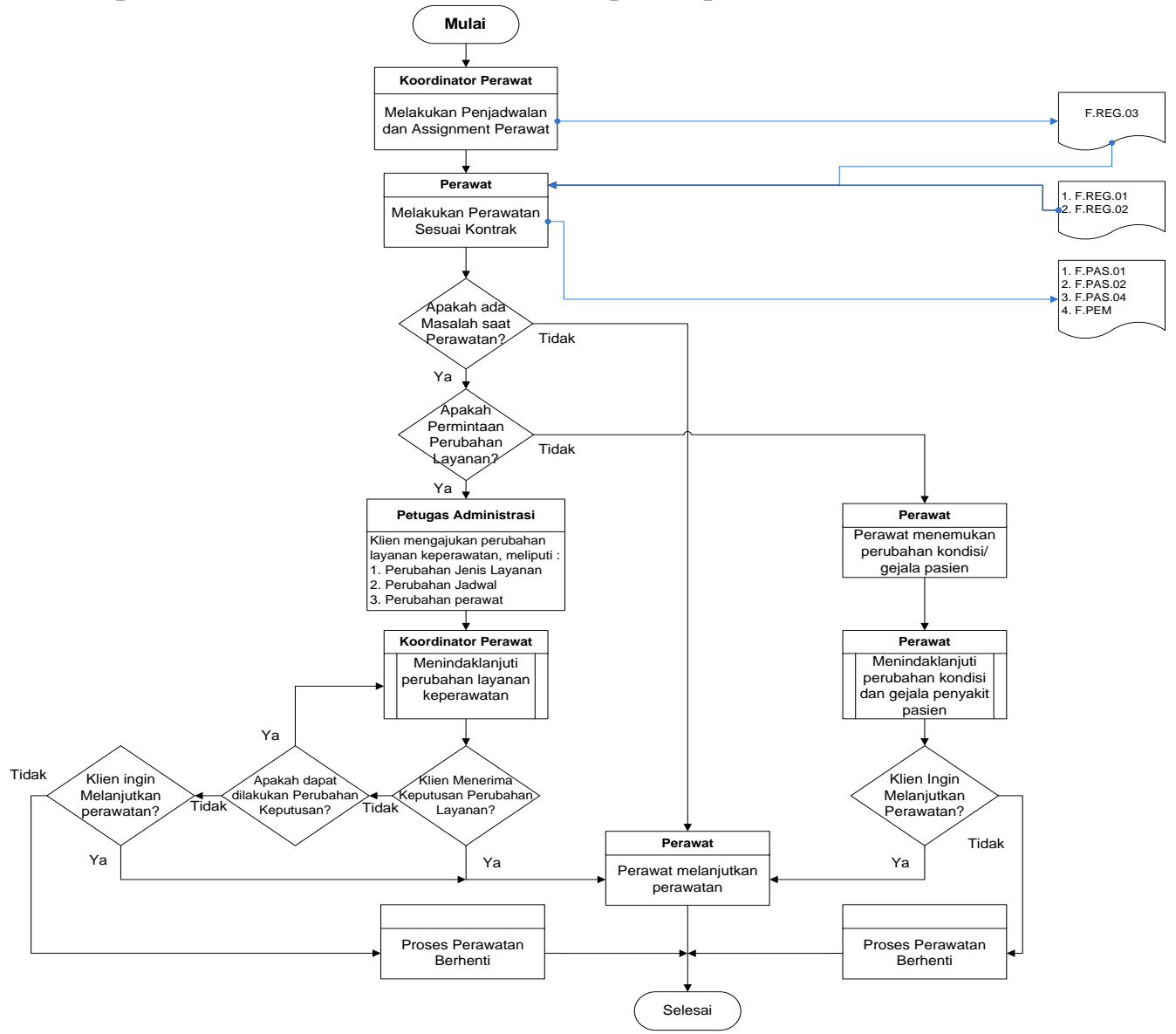

Gambar 1. Proses Perawatan Awal 


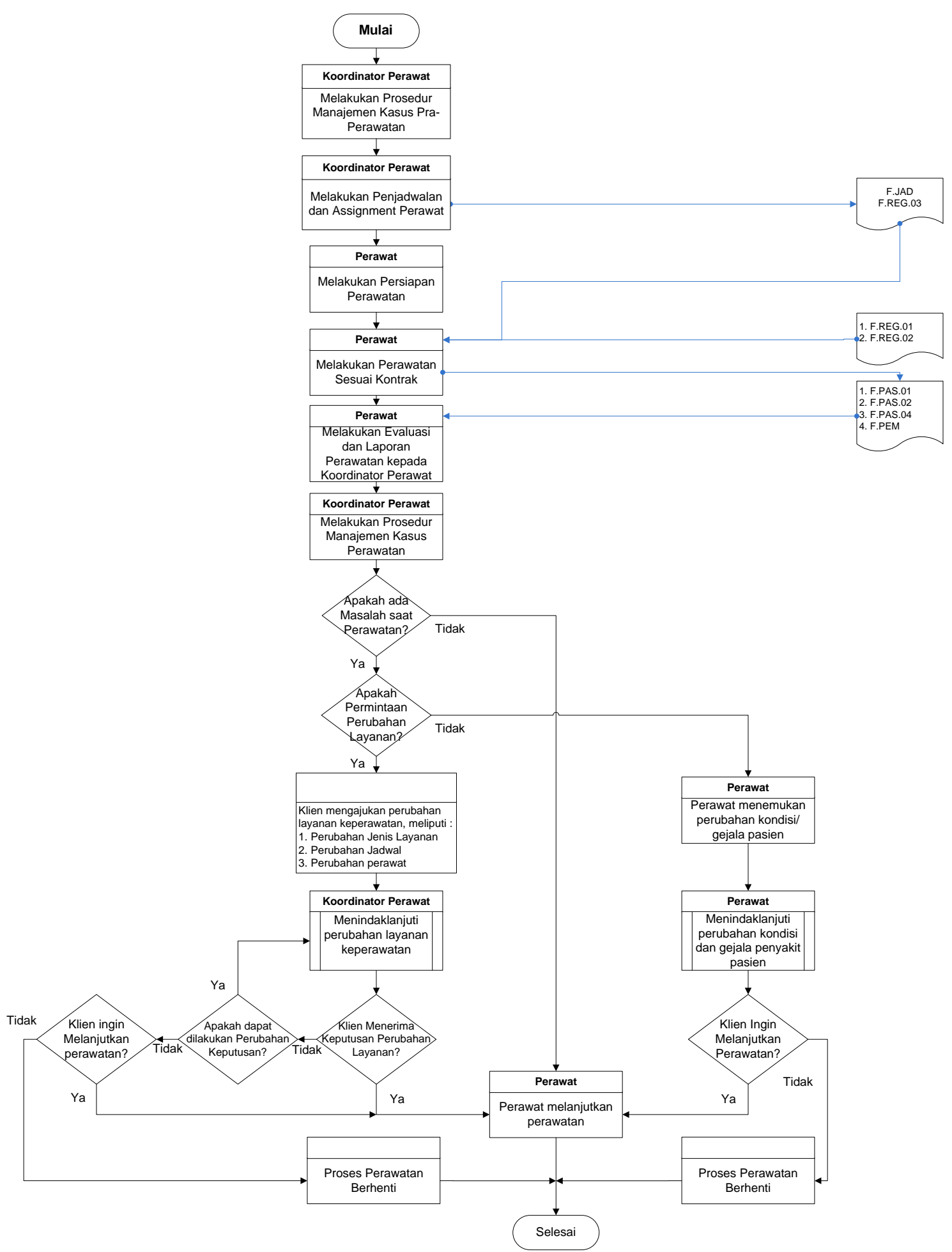

Gambar 2. Proses Perawatan Usulan

\subsection{Perancangan Struktur Organisasi Usulan}

Perancangan struktur organisasi usulan dilakukan berdasarkan pada hasil perancangan proses bisnis usulan dan struktur organisasi awal perusahaan. Struktur organisasi awal ProNers Home Care and Nursing Solution dapat dilihat pada Gambar 3. 


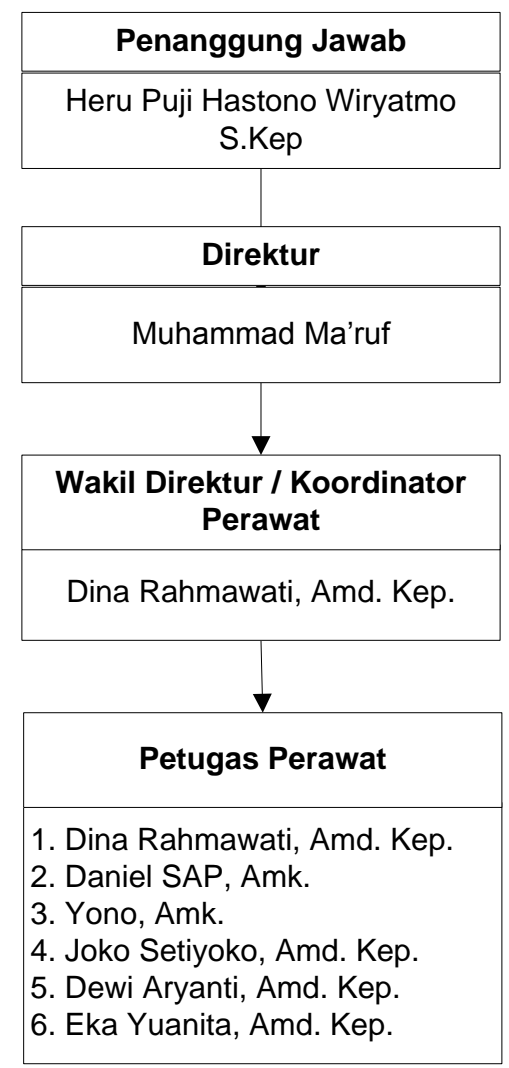

Gambar 3. Struktur Organisasi Awal

Hasil perancangan struktur organisasi usulan untuk ProNers Home Care and Nursing Solution dapat dilihat pada Gambar 4.

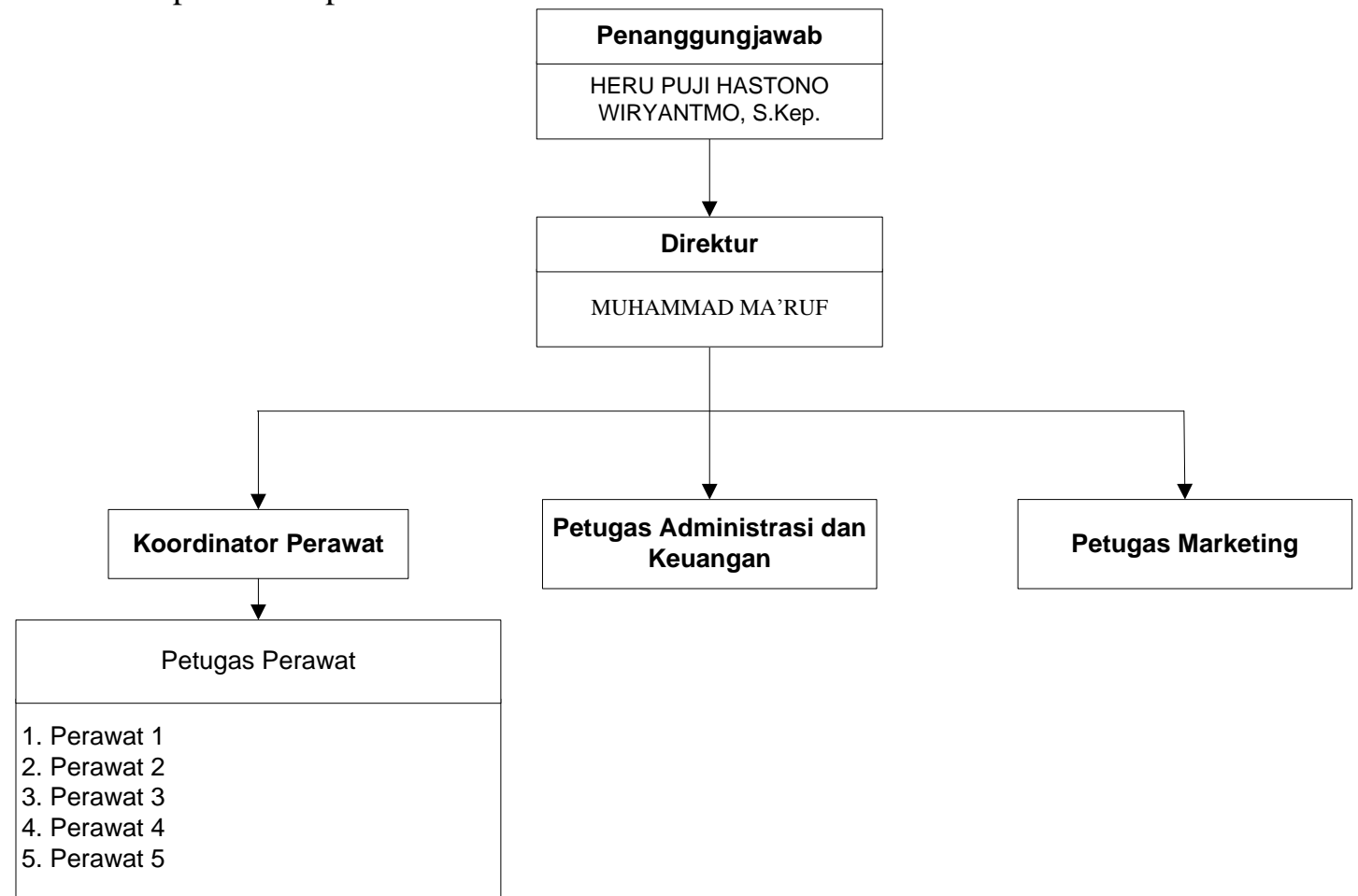

Gambar 4. Struktur Organisasi Usulan 
Struktur organisasi usulan termasuk struktur organisasi matriks dengan spesialisasi yang lebih fokus. Sebelumnya tidak terdapat bagian administrasi dan keuangan dan bagian marketing. Tugas direktur sebelumnya dibantu oleh seorang wakil direktur.

Jabatan wakil direktur diusulkan untuk dihilangkan, karena tanggung jawab seorang wakil direktur yang berkaitan dengan pengambilan keputusan apabila direktur berhalangan berdasarkan kondisi perusahaan saat ini kurang diperlukan. Sebagai gantinya diusulkan direktur dapat memberikan kuasa pada bawahannya untuk mengambil keputusan terkait dengan bidang masing-masing bagian. Direktur dapat meminta pertanggungjawaban tiap bagian setelahnya.

Diusulkan pembentukan bagian administrasi dan keuangan dan bagian marketing. Bagian administrasi dan keuangan akan bertanggung jawab atas tugas dan pekerjaan administratif dan pengelolaan keuangan perusahaan, sedangkan bagian marketing bertanggung jawab atas tugas dan pekerjaan promosi dan pemasaran perusahaan.

\subsection{Perancangan Standard Operating Procedure (SOP) Usulan}

Setelah dilakukan perancangan proses bisnis usulan, untuk mendapatkan tujuan dari proses bisnis maka perlu dijabarkan lebih detail setiap proses bisnis ke dalam prosedur yang disebut dengan SOP. Dalam perancangan SOP ini, akan dijabarkan mengenai SOP yang diperlukan beserta komponen-komponennya (tujuan, ruang lingkup, tanggung jawab dan dokumen). SOP yang dibuat terdiri dari 19 SOP yang meliputi sebagai berikut :

1. Proses Registrasi

a. Penerimaan calon klien dan penjelasan informasi layanan

b. Pelayanan SBR

c. Pengecekan jadwal perawat

d. Konfirmasi Mitra

2. Proses Perawatan

a. Manajemen kasus pra-perawatan

b. Penjadwalan dan Assignment perawat

c. Kelengkapan (Nursing Kit) perawat saat melakukan kunjungan perawatan

d. Menjaga keamanan dan keselamatan diri perawat

e. Menjaga klien dalam satu shift

f. Home Visiting

g. Pergantian perawat dan jadwal pelayanan

h. Perubahan jenis layanan perawatan

i. Perubahan kondisi/gejala klien

j. Penanganan kegawat-daruratan yang dialami klien

k. Manajemen kasus perawatan

3. Proses Pembayaran

a. Pembayaran di rumah klien

b. Pembayaran di kantor ProNers

c. Pembayaran via transfer

4. Proses Penerimaan Komplain

a. Penerimaan Komplain

Contoh hasil SOP yang dihasilkan, yaitu SOP Home Visiting dapat dilihat pada Gambar 6. Dan untuk keterkaitan antar SOP yang dihasilkan dapat dilihat pada Tabel 1. 


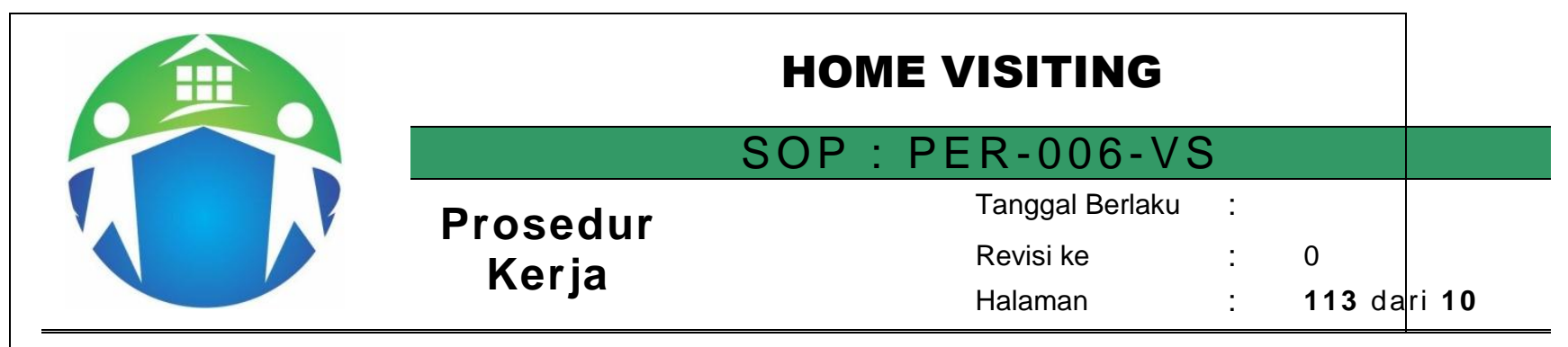

Penanggung Jawab

\begin{tabular}{lcc}
\hline Disiapkan & Diperiksa & Disahkan \\
\hline
\end{tabular}

Nama:

Nama:

Nama:

Jabatan:

Jabatan:

Jabatan:

\section{TUJUAN}

Standard Operating Procedur (SOP) ini mendeskripsikan langkah-langkah dan tindakan yang harus diperhatikan oleh perawat dalam mengakomodasi proses Home Visiting.

2. Ruang lingkup

Setiap karyawan dan perawat Proners harus memiliki perhatian dan pengetahuan yang utuh terhadap prosedur kerja yang disajikan dalam dokumen ini. Direktur menyampaikan prosedur kerja ini kepada setiap karyawan baru atau perawat baru pada masa orientasi karyawan atau perawat.

Dokumen ini menjelaskan proses yang dilakukan oleh perawat sebagai bagian dari prosedur kegiatan Home Visiting. Prosedur ini dilaksanakan berdasarkan instruksi direktur di kantor ProNers kepada karyawan dan perawat ProNers terkait adanya pelayanan perawatan jenis visit.

3. Penanggung jawab

$\checkmark$ Perawat bertanggung jawab melakukan tugas menjaga dan merawat klien secara baik dalam jangka waktu Home Visiting yang diberikan.

$\checkmark$ Perawat bertanggung jawab mendokumentasikan data selama perawatan berlangsung dalam formulir perawatan yang tersedia.

4. Definisi, Akronim dan Singkatan

- Perawat

: Karyawan ProNers Home Care yang memiliki fungsi dan

- SOP

5. Alat dan bahan keahlian sebagai perawat

: Standard Operating Procedure (Standar Prosedur Operasional)

Peralatan yang dibutuhkan dalam pelaksanaan prosedur Home Visiting sebagai berikut:

$\checkmark$ Alat tulis

$\checkmark$ Formulir perawatan

$\checkmark$ Stopmap

$\checkmark$ Nursing Kit

6. Deskripsi Proses (Langkah-Langkah)

Proses ini dilaksanakan berdasarkan instruksi direktur di kantor ProNers kepada karyawan dan perawat PHC terkait adanya program perawatan klien jenis Home Visiting. Langkah-langkah perawatan dalam Home Visiting adalah sebagai berikut::

1. Memulai kegiatan dengan membaca basmalah.

2. Berpakaian rapi dan sopan sesuai syariat islam.

3. Perawat melakukan absensi pada formulir absensi.

4. Perawat membaca laporan perawatan yang dibuat perawat sebelumnya.

5. Perawat melakukan observasi keadaan umum pasien.

6. Melakukan cek vital sign.

7. Memenuhi kebutuhan dasar dan perawatan klien sesuai kebutuhan klien.

8. Melaporkan kondisi klien kepada dokter konsulen dan perawat senior apabila diperlukan.

9. Melaporkan kondisi klien kepada keluarga. 
10. Mencatat laporan kegiatan di formulir Perawatan Klien.

11. Mengakhiri kegiatan dengan membaca hamdalah.

7. Dokumen Pendukung dan Formulir

Dokumen atau formulir berikut ini perlu diperhatikan untuk mendapatkan informasi yang lebih detail dalam pelaksanaan prosedur Home Visiting

\begin{tabular}{lll}
\hline Kode Dokumen & Nama Dokumen & Keterangan \\
\hline F.PAS.01, & $\begin{array}{l}\text { Program Keperawatan } \\
\text { Klien }\end{array}$ & $\begin{array}{l}\text { Berisi Diagnosis Keperawatan dan tindakan Keperay } \\
\text { dilakukan. }\end{array}$ \\
Frogram Keperawatan & $\begin{array}{l}\text { Berisi tindakan keperawatan yang dilakukan dijabark } \\
\text { KOAP }\end{array}$ \\
Klien (SOAP) & Surat Konsultasi Dokter & $\begin{array}{l}\text { Berisi laporan kondisi medis klien tertentu untuk dikon } \\
\text { kepada dokter. }\end{array}$ \\
F.PAS.03, & Laporan Kesehatan Klien & Berisi rincian kondisi kesehatan klien tertentu. \\
F.ABSEN & Absensi Perawat &
\end{tabular}

8. Pelatihan dan Standar Kompetensi yang Dibutuhkan

Perawat :

- Komunikasi efektif dengan pasien dan keluarga

- Keteraturan dan kedisiplinan

- Pengendalian diri dan profesionalitas

- Penguasaan pengetahuan keperawatan

9. Audit Dokumen

Direktur bertanggung jawab terhadap pelaksanaan SOP ini. Direktur dapat membentuk tim internal maupun menunjuk tim eksternal untuk melakukan audit secara berkala. Audit dilakukan terhadap deskripsi proses, diagram alir dan dokumen penunjang atau formulir-formulir.

Karyawan dan perawat diminta untuk memberikan evaluasi secara berkesinambungan terhadap kelemahan SOP ini dikaitkan dengan kondisi terkini dalam proses Home Visiting.

10. Histori Perubahan

Gambar 6. Contoh SOP 
Tabel 1 Keterkaitan antar SOP

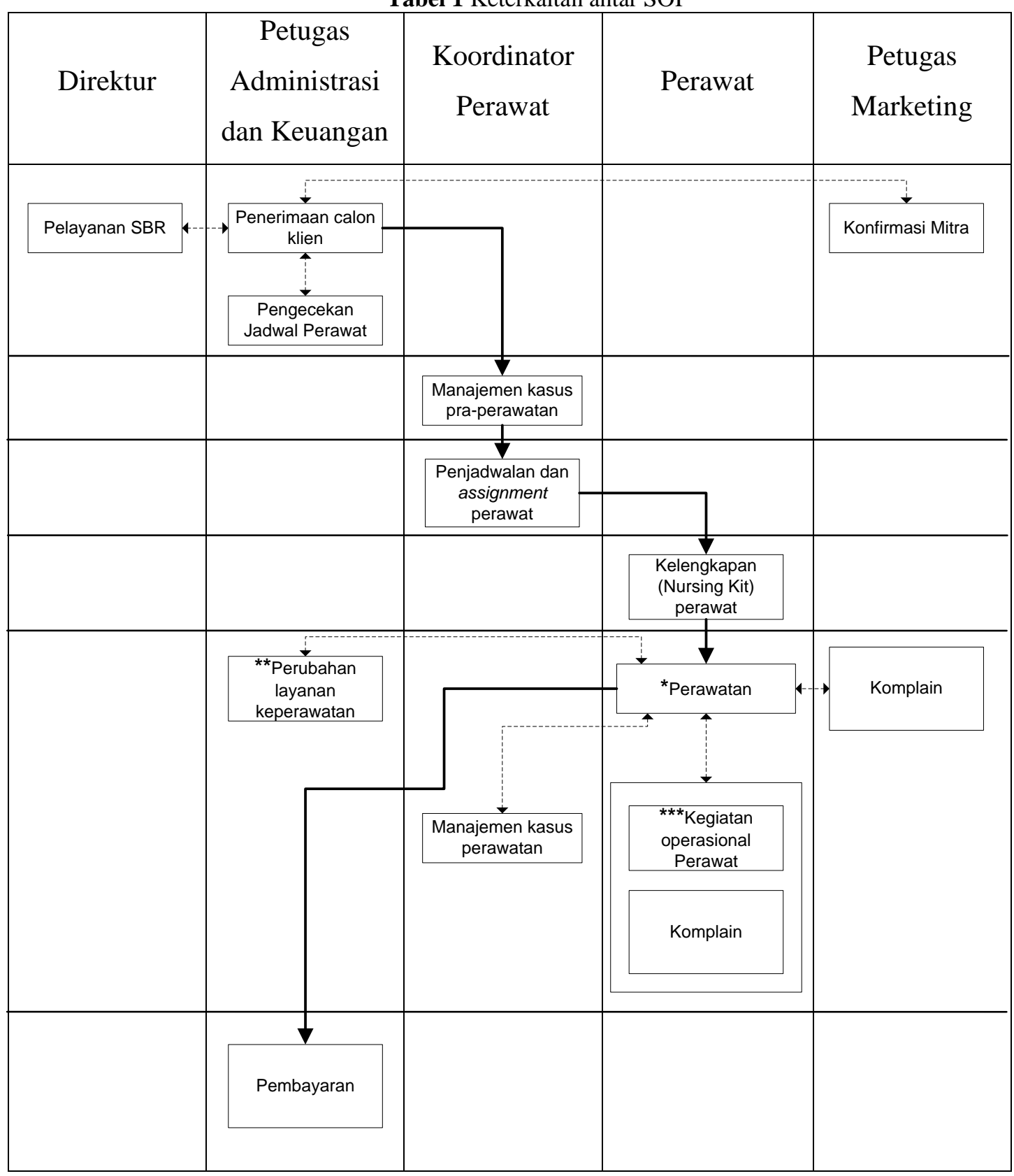

Keterangan:

: Menunjukkan prosedur sesudahnya dapat dilakukan setelah prosedur sebelumnya selesai dilakukan.

$\longrightarrow$ : Menunjukkan prosedur dapat dilakukan selama prosedur lain sedang berlangsung.

Tanda * : Prosedur dapat dijabarkan menjadi beberapa prosedur detail

\section{Kesimpulan}

Penelitian yang dilakukan menghasilkan proses bisnis usulan ProNers Home Care and Nursing Solution yang dirancang menggunakan metode Business Process Improvement (BPI) dengan pendekatan Process Reengineering. Hasil rancangan proses bisnis usulan kemudian untuk merancang struktur organisasi usulan dan Standard Operating Procedure (SOP) usulan.

Struktur organisasi usulan yang dihasilkan berupa struktur organisasi matriks dengan spesialisasi pekerjaan yang lebih fokus. Spesialisasi pekerjaan tersebut adalah adanya 
penambahan bagian administrasi dan keuangan dan bagian marketing. Dengan penambahan dua bagian tersebut, diperlukan penambahan SDM sebanyak dua orang, 1 orang bertanggung jawab pada bagian administrasi dan keuangan dan 1 orang bertanggung jawab pada bagian marketing.

Hasil rancangan proses bisnis usulan juga digunakan sebagai dasar perancangan SOP usulan. SOP yang dirancang merupakan penjabaran detail setiap proses atau kegiatan yang terdapat dalam setiap proses bisnis. SOP yang diusulkan terdiri dari 19 SOP. Dari kesembilan belas SOP yang telah dibuat, semua telah mewakili prosedur dan proses yang ada di lapangan. Tetapi ada beberapa dari prosedur SOP yang dirasa kurang oleh staf ProNers Home Care and Nursing Solution maupun dirasa terdapat prosedur yang tidak perlu. Hal tersebut dapat diatasi dengan melakukan perbaikan berupa penambahan maupun pengurangan prosedur pada SOP tersebut.

Penelitian lanjutan yang dapat dilakukan setelah penelitian ini adalah merancang sistem informasi untuk mendukung dan mempermudah pelaksanaan proses bisnis dan SOP usulan yang telah dirancang pada penelitian ini.

\section{Daftar Pustaka}

Ahadi, H.R. 2004. An Examination of The Role of Organizational Enablers in Business Process Reengineering and The Impact of Information Technology, Information Resource Management Journal, Vol. 17 No. 4, hal 1-19.

Chong, S. (2007). Business Process Management for Smes: An Exploratory Study of Implementation Factors for The Australian Wine Industry, Journal of Information Systems and Small Business, Vol. 1, No. 1-2, hal. 41-58.

Harrington. 1991. Bussiness Process Improvement: The Breakthrough Strategy for Total Quality, Productivity, and Competitiveness. New York: McGraw-Hill.

Indrajit, R.E dan Djoko R. 2001. Konsep dan Aplikasi Bussiness Process Reengineering. Tersedia di http://www.docin.com/p-94431527.html. Diakses tanggal 10 November 2013.

Robbins, S. P. 2002. Organizational Behavior: Concepts, Controversies, and Applications eighth edition. Edisi Revisi. Alih bahasa oleh Dr. Hadyana Pujaatmaka dan Drs. Benyamin Molan. Jakarta: PT. Prenhallindo.

Zaheer, A., Rehman, K.U., dan Khan, M.A., 2010. Development and Testing of A Business Process Orientation Model to Improve Employee and Organizational Performance. African Journal of Business Management, Vol.4 No.2, hal. 149-161. 